\title{
POTENSI TEKNIS PEMANFAATAN PELEPAH NIPAH DAN CAMPURANNYA DENGAN SABUT KELAPA UNTUK PEMBUATAN PAPAN SERAT BERKERAPATAN SEDANG
}

\author{
(Technical Potency on the Use of Nypa Midrib and Its Mixture with Coconut Coir \\ for the Manufacture of Medium-Density Fiberboard)
}

\author{
Han Roliadi, Dian Anggraini Indrawan, Gustan Pari \& Rossi Margareth Tampubolon ${ }^{1}$ \\ ${ }^{1}$ Pusat Penelitian dan Pengembangan Keteknikan Kehutanan dan Pengolahan Hasil Hutan \\ Jln. Gunung Batu No. 5 Bogor 16610, Tlp/Fax (0251) 8633378 / 8633413 \\ e-mail: han_roliadi@yahoo.com
}

Diterima 31 Januari 2012, disetujui 2 Juli 2012

\begin{abstract}
Indonesia's tropical natural forest woods are conventionally still raw materials for MDF, which in potency becomes depleted and scarce. Consequently, use of alternative fibrous materials deserves thorough consideration, with theirpotencies abundant and mostly still unutilized, such as Nypa frutican midrib and coconut coir. In relevant, an experiment was conducted to utilize both kinds of fiber for $M D F$.

Those fiber stuffs were each passed through the preparation, and examination of their basic properties (i.e. specific gravity, chemical composition, and fiber dimensions and their derived values). The fibrous pulping for MDF employed a hot semi-chemical soda process under atmospheric pressure, followed with the refining action to achieve pulp freeness at 600-700 $m l$ CSF. The refined pulp were then added with additives (i.e. 4\% alum, 3\% UF-adhesive, 5\% activated charcoal), and then shaped into MDF mat using wet process, followed with heat treatment, hot pressing, conditioning, and ultimately the testing of MDFproperties.

Scrutiny on MDF physico-strength properties revealed that nypa-midrib fibers were more prospective for MDF than coconut-coir fibers. Activated-charcoal addition lowered the MDF formaldehyde-emission, but decreased its strengths. In properties, MDFs from nyp a fibers significantly outperformed those from coconut-coir fibers in complying with the standard (JIS). Yet, coconut-coir fiv ers could still be prospective for MDF by mixing them (pulp form) with nypa-fiber pulp at the proportion $(w / w): 25 \%+75 \%$ and $50 \%+50 \%$.
\end{abstract}

Keywords: MDF, nypa frutican midrib and coconut coir, physical and strength properties, formaldebyde emission

\begin{abstract}
ABSTRAK
Kayu hutan alam tropis Indonesia masih merupakan bahan baku konvensional papan serat berkerapatan sedang (MDF), di mana potensinya semakin berkurang dan langka. Oleh karena itu penggunaan bahan baku serat alternatif perlu dipertimbangkan, di mana potensinya berlimpah dan sebagian besar belum dimanfaatkan, seperti pelepah nipah dan sabut kelapa. Dalam kaitannya, telah dilakukan percobaan pemanfaatan dua macam bahan serat tersebut untuk MDF.

Masing-masing bahan serat tersebut mengalami tahapan persiapan, dan pemeriksaan sifat dasar (berat jenis, komposisi kimia, dan dimensi serat berikut nilai turunannya), lalu dilakukan pengolahan pulp menggunakan proses semi-kimia soda panas terbuka, dilanjutkan dengan penggilingan hingga pulp mencapai derajat kehalusan 600-700 ml CSF. Pada pulp ditambahkan bahan aditif (alum 4\%, perekat urea formaldehida $3 \%$, dan arang aktif $5 \%$ ) dan kemudian dibentuk menjadi lembaran MDF
\end{abstract}


dengan cara basah. Selanjutnya dilakukan pengempaan panas, conditioning, dan pengujian sifat MDF.

Pencermatan terhadap sifat fisis dan kekuatan MDF menunjukkan bahwa serat pelepah nipah lebih prospektif untuk MDF dari pada serat sabut kelapa. Penggunaan arang aktif menurunkan emisi formaldehida MDF tetapi menurunkan sifat kekuatannya. Sifat MDF dari serat pelepah nipah lebih banyak memenuhi persyaratan standar (JIS) dibandingkan dari serat sabut kelapa. Meskipun demikian, serat pelepah nipah bisa bermanfaatan untuk MDF, dengan mencampurmya (bentuk pulp) dengan pulp pepepah nipah (b/b) pada proporsi: $25 \%+75 \%$ dan $50 \%+50 \%$.

Kata kunci: MDF, pelepah nipah dan sabut kelapa, sifat fisis dan kekuatan, emisi formaldehida

\section{PENDAHULUAN}

Kayu merupakan bahan serat yang umum digunakan untuk pembuatan papan serat berkerapatan sedang (MDF). Namun demikian, kayu hutan tropis alam sebagai bahan baku konvensional untuk MDF potensinya semakin terbatas dan langka (Kompas, 2006). Fakta ini mendorong penggunaan bahan serat berlignoselulosa lain (bukan kayu) untuk MDF seperti pelepah nipah dan sabut kelapa, di mana potensinya cukup berlimpah dan belum banyak dimanfaatkan.

Nipah (Nypa frutican Wumb) merupakan jenis palma (palm) yang banyak tumbuh di lingkungan hutan bakau (mangrove forest), di daerah pasangsurut dekat tepi laut, atau lepas pantai (De Bos dan Adnan, 1958; Wikipedia, 2009). Pelepah nipah merupakan bahan serat berligno-selulosa, sehingga diharapkan dapat dimanfaatkan untuk pembuatan pulp, kertas, dan turunan selulosa lainnya, termasuk papan serat (Diydata, 2010). Luas hutan nipah di Indonesia mencapai 20-30 juta ha (Dephut, 2008; P3KKPHH, 2010), sehingga potensi pelepah yang dihasilkan oleh tanaman nipah cukup potensial sebagai bahan berserat ligno-selulosa sekiranya dimanfaatkan untuk MDF.

Bahan alternatif lain yang terdapat dalam jumlah besar adalah sabut kelapa. Sabut kelapa merupakan bagian mesokarp buah kelapa, dan menyusun sekitar 30\% dari total berat buah kelapa (Iskandar dan Supriadi, 2010). Pohon kelapa (Cocos nucifera), sama halnya dengan nipah, juga termasuk golongan monokotil. Diperkirakan areal tanaman kelapa di Indonesia mencapai sekitar 3,2 juta ha pada tahun 2007, dan produksi buah kelapa di tahun yang sama sebesar 5,6 juta ton (Departemen Kehutanan, 2008). Atas dasar itu diperkirakan potensi sabut kelapa Indonesia sebesar 1,7 juta ton per tahun. Sabut kelapa juga mengandung selulosa, lignin, hemiselulosa, dan bahan ekstraktif (Arsyad, 2010). Dengan demikian, secara teknis sabut tersebut dapat dimanfaatkan untuk pulp, kertas, dan MDF.

Tulisan ini melaporkan hasil percobaan pemanfaatan pelepah nipah untuk MDF, dan campurannya dengan sabut kelapa pada berbagai proporsi.

\section{BAHAN DAN METODE}

\section{A. Bahan dan Alat}

Bahan baku yang digunakan adalah pelepah nipah dan sabut kelapa. Contoh pelepah nipah diambil dari daerah Malingping (Provinsi Banten) dan Pangandaran, Kabupaten Ciamis (Provinsi Jawa Barat). Dalam pembentukan lembaran papan serat digunakan bahan aditif berupa aluminium sulfat (tawas), perekat urea formaldehida, dan arang aktif.

Peralatan yang digunakan untuk pembuatan papan serat skala kecil adalah ketel pemasak, bak pencuci serpih hasil pemasakan, Hollander beater, alat freeness tester. fiberboard-mat former (deckle box), stock chest, dan mesin pengempa dingin dan panas. Peralatan untuk pengujian sifat fisik dan kekuatan/mekanik papan serat adalah universal testing macbine (UTM); dan untuk mencermati karakteristik bahan baku serat berskala nano digunakan instrumen XRD (X-ray diffraction).

\section{B. Metode}

1. Sifat dasar bahan baku serat

a. Berat jenis, kadar air, dan analisis komposisi kimia 
Pemeriksaan berat jenis, kadar air, dan analisis komposisi kimia bahan serat (pelepah nipah dan sabut kelapa) dilakukan menurut standar TAPPI (TAPPI Press, 2006a), yang mencakup kadar selulosa, kadar lignin, kadar holoselulosa, kadar alfa-selulosa, kadar pentosan, kadar hemiselulosa, kadar abu, kadar silika, kelarutan dalam alkohol-benzena 1:2, kelarutan dalam $\mathrm{NaOH} 1 \%$.

\section{b. Dimensi serat dan nilai turunannya}

Pemeriksaan dimensi serat dan nilai turunannya dilakukan menurut Prosedur Lembaga Penelitian Hasil Hutan (Silitonga et al., 1972), yang mencakup panjang serat (L), diameter serat (d) dan diameter lumen (l), tebal dinding serat (w), bilangan Runkel (2w/l), bilangan Muhlstep $\left(100^{*}\left[\mathrm{~d}^{2}-\mathrm{l}^{2}\right] / \mathrm{d}^{2}\right)$, daya tenun $(\mathrm{L} / \mathrm{d})$, koefisien kekakuan (w/d), dan kelemasan (koefisien fleksibilitas) serat $(1 / d)$.

\section{Pembuatan pulp nipah dan pulp sabut kelapa}

a. Penyiapan serpih pelepah nipah dan serpih sabut kelapa

Pelepah nipah dan sabut kelapa secara terpisah dijadikan serpih berukuran panjang 2-3 cm, lebar 2-2,5 $\mathrm{cm}$, dan tebal 2-3 mm secara manual, dan selanjutnya dikeringkan di tempat terbuka (di bawah atap) hingga mencapai kadar air kering udara.

b. Pemasakan serpih nipah dan serpih sabut kelapa menjadi pulp

Serpih pelepah nipah dan serpih sabut kelapa, yang masing-masing telah mencapai kadar air kering udara secara terpisah dimasak pada ketel pemasak berkapasitas per batch $50 \mathrm{~kg}$ serpih kayu kering oven (atau $125 \mathrm{~kg}$ serpih kayu basah) dengan menggunakan proses semi kimia soda panas terbuka. Pemasakan serpih bahan serat tersebut dilakukan dengan tiga variasi konsentrasi alkali $(\mathrm{NaOH})$ yaitu $4 \%, 8 \%$, dan $12 \%$ (berdasarkan berat kering bahan serat) pada suhu mendidih air $\left(100^{\circ} \mathrm{C}\right)$ selama 3 jam. Kondisi tetap pemasakannya adalah nilai banding bahan baku serat terhadap larutan pemasak sebesar 1: $8(\mathrm{~b} / \mathrm{v})$. Selesai pemasakan, serpih lunak dipisahkan dari larutan pemasak dan dicuci dengan air sampai bebas bahan kimia pemasak. Dari sisa larutan pemasak (yang sudah mengalami pengenceran akibat penggunaan air pencuci tersebut) diambil contoh untuk keperluan pemeriksaan konsumsi alkali. Serpih lunak hasil pencucian selanjutnya dicerai-beraikan hingga menjadi serat-serat terpisah (pulp) menggunakan alat Hollander beater pada konsistensi 3-4\% hingga mencapai derajat kehalusan $600-700 \mathrm{ml} \mathrm{CSF}\left(15-17^{\circ} \mathrm{SR}\right)$. Pulp yang diperoleh selanjutnya diturunkan kadar airnya menggunakan alat centrifuge, dan selanjutnya ditentukan rendemennya.

Dalam pemasakan serpih pelepah nipah dan serpih sabut kelapa secara terpisah menjadi pulp, pertama-tama dicermati waktu giling oleh masingmasing pulp yang dibutuhkan guna mencapai derajat kehalusan sekitar 600-700 ml CSF (15$\left.17^{\circ} \mathrm{SR}\right)$. Bila perbedaan waktu giling tersebut tidak berbeda nyata, maka campuran dilakukan dalam bentuk bahan baku (serpih pelepah nipah dan serpih sabut kelapa, dengan proporsi berat berturut-turut $100 \%+0 \%, 75 \%+25 \%$, $50 \%+50 \%$ dan $0 \%+100 \%$ ). Akan tetapi, sekiranya perbedaan waktu giling tersebut nyata, maka campuran pelepah nipah dan sabut kelapa dalam bentuk pulp (pulp pelepah nipah dan pulp sabut kelapa, dengan proporsi berat berturutturut $100 \%+0 \%, 75 \%+25 \%, 50 \%+50 \%$ dan $0 \%+100 \%$ ).

\section{c. Pembentukan lembaran MDF}

Pembentukan lembaran papan serat dilakukan dengan cara basah. Sebelum pembentukan lembaran, pulp dari tiap taraf proporsi campuran serat pelepah nipah dan sabut kelapa (atau campuran dalam bentuk pulp) disuspensikan dengan media air hingga mencapai konsistensi 3$4 \%$ pada Hollander beater skala semi-pilot, selanjutnya dilakukan sirkulasi hingga terbentuk suspensi pulp-air yang homogen. Sambil terus disirkulasi, ditambahkan bahan aditif berupa aluminum sulfat (tawas) sebanyak $4 \%$, perekat urea formaldehida (UF) (3\%), dan arang aktif pada 2 taraf secara terpisah ( $0 \%$ dan $5 \%$ ). Campuran tersebut terus disirkulasi hingga homogen. Sebagai pembanding (kontrol) dibuat suspensi pulp-air untuk MDF tanpa perekat (juga tanpa tawas dan tanpa arang aktif), dengan 
prosedur yang sama. Selanjutnya sesudah homogenisasi, campuran pulp (dengan atau tanpa aditif) siap dibentuk menjadi lembaran papan serat bertipe kerapatan sedang (MDF) dengan target kerapatan $0,70 \mathrm{~g} / \mathrm{cm}^{3}$, berukuran $30 \mathrm{~cm} \mathrm{x}$ $30 \mathrm{~cm} \times 1 \mathrm{~cm}$, menggunakan alat deckle box (cara basah). Selanjutnya dilakukan pengempaan dingin (suhu kamar, tekanan $5 \mathrm{~kg} / \mathrm{cm}^{2}$ ), dilanjutkan dengan perlakuan panas selama 30 menit, dan pengempaan panas (suhu $170^{\circ} \mathrm{C}$, tekanan $30 \mathrm{~kg} / \mathrm{cm}^{2}$, selama 10 menit). Lembaran MDF yang terbentuk selanjutnya dikondisikan pada ruang bersuhu dan berkelembaban tertentu selama 24 jam, dan siap diuji sifat fisis dan kekuatan/mekanis serta emisi formaldehidanya.

\section{Pengujian}

\section{a. Sifat pengolahan pulp}

Pengujian tersebut mencakup rendemen pulp, konsumsi alkali, derajat kehalusan, dan waktu mencapai derajat giling mencapai $600-700 \mathrm{ml} \mathrm{CSF}$ $\left(15-17^{\circ} \mathrm{SR}\right)$, yang dilakukan menurut standar TAPPI (TAPPI Press, 2006).

b. Sifat fisis dan mekanis MDF

Pengujian sifat fisis dan mekanis MDF, dan emisi fermaldehida mengacu pada standar JIS (JIS, 2003)

\section{c. Pencermatan dengan XRD}

Pencermatan ini dilakukan sebagai tambahan atau pelengkap data/informasi yang diperoleh dari hasil pengujian secara konvensional, yaitu mencermati karakteristik berskala nano pada bahan baku (serat pelepah nipah dan serat sabut kelapa), menggunakan instrumen XRD.

\section{Rancangan percobaan dan analisis data}

Untuk menelaah data sifat dasar (berat jenis, kadar air, komposisi kimia, dimensi serat dan nilai turunannya) digunakan rancangan acak lengkap satu faktor. Sebagai faktor adalah macam bahan serat yaitu pelepah nipah (s1) dan sabut kelapa (s2). Pengamatan terhadap sifat masing-masing bahan serat dilakukan sebanyak 8-10 kali.

Untuk menelaah data sifat pemasakan pulp untuk papan serat, digunakan rancangan acak lengkap faktorial. Sebagai faktor (perlakuan) adalah macam bahan serat $(\mathrm{S})$ yaitu pelepah nipah (s1) dan sabut kelapa (s2); dan konsentrasi alkali (A) dalam 3 taraf yaitu 4\% (a1), $8 \%$ (a2), dan 12\% (a3). Setiap taraf dari kombinasi kedua faktor tersebut $\left(\mathrm{S}^{*} \mathrm{~A}\right)$ diulang sebanyak 5 kali.

Selanjutnya data sifat fisis dan mekanis lembaran papan serat tipe MDF berikut emisi formaldehida ditelaah dengan rancangan acak lengkap berpola faktorial. Sebagai faktor adalah konsentrasi alkali (A) dalam 3 taraf (a1 $=4 \%$, $\mathrm{a} 2=8 \%$, dan $\mathrm{a} 3=12 \%$ ); proporsi campuran bahan serat (atau bentuk pulp) antara pelepah nipah dengan sabut kelapa (B) dalam 4 taraf yaitu $100 \%+0 \%$ (b1), $75 \%+25 \%$ (b2), $50 \%+50 \%$ (b3), dan $0 \%+100 \%$ (b4); dan penambahan bahan aditif (C) dalam 3 taraf yaitu tanpa aditif/kontrol (c1); perekat UF 3\% + tawas 5\% (c2); dan perekat UF $3 \%+$ arang aktif $5 \%+$ tawas $5 \%$ (c3). Setiap taraf dari kombinasi faktor-faktor tersebut (ABC) dilakukan ulangan sebanyak 3 kali.

Bila pengaruh faktor-faktor baik dalam pengolahan pulp ( $\mathrm{S}, \mathrm{A}$, dan interaksi $\mathrm{SA}$ ), ataupun dalam pembentukan lembaran $\operatorname{MDF}(\mathrm{A}, \mathrm{B}, \mathrm{C}$, dan interaksi $\mathrm{AB}, \mathrm{AC}, \mathrm{BC}$, atau $\mathrm{ABC}$ ) nyata, maka peneleaahan dilanjutkan dengan uji beda nyata jujur (BNJ) (Snedecor dan Cochran, 1980). Lebih lanjut untuk memperoleh indikasi lebih meyakinkan apakah serat pelepah nipah atau serat sabut kelapa yang berpotensi atau berpeluang lebih besar untuk produk jadi (MDF), maka digunakan telaahan lebih lanjut dengan analisis diskriminan berikut koefisien determinasi kanonik (SAS Institute Inc, 1997; Morrison, 2003).

\section{HASIL DAN PEMBAHASAN}

\section{A. Sifat Dasar Bahan Serat}

1. Kadar air, berat jenis, dan komposisi kimia

Analisis keragaman terhadap kadar air, berat jenis, dan komposisi kimia menunjukkan bahwa perbedaan macam bahan serat (pelepah nipah dan sabut kelapa) berpengaruh nyata (F-hitung dengan peluang $(\mathrm{P})<0,05$ atau 0,01$)$. Penelaahan lebih lanjut diteruskan dengan uji $\mathrm{BNJ}(\mathrm{P}<0,05)$, yang antara lain menunjukkan bahwa berat jenis sabut kelapa $(0,18)$ lebih rendah dibandingkan dengan pelepah nipah $(0,21)$. Mungkin ini karena sabut kelapa memiliki tebal dinding serat lebih 
tipis $(1.95 \mu \mathrm{m})$ dan volume/diameter rongga lumen $(25,2 \mu \mathrm{m})$ lebih besar dibandingkan pelepah nipah (berturut-turut 2,43 $\mu \mathrm{m}$ dan 19,38 $\mu \mathrm{m})$. Kadar air nipah $(11,37 \%)$ sedikit lebih tinggi dari pada sabut kelapa (10,41\%). Dalam hal kadar abu, kadar silika, kadar hemiselulosa, kelarutan dalam alkohol-benzena 1:2, kelarutan dalam air dingin, kelarutan dalam air panas, dan kelarutan dalam $\mathrm{NaOH} 1 \%$, nilai pada nipah (berturut-turut $13,80 \%, 1,33 \%, 21,77 \%, 42,85 \%$ ) lebih tinggi dibandingkan dengan sabut kelapa 2,01\%, 0,89\%, $5,61 \%, 21,49 \%$ ). Sebaliknya, untuk kadar lignin, kadar selulosa, kadar holoselulosa, dan kadar pentosan, nilainya pada nipah lebih rendah $(21,80 \%, 34,82 \%, 54,72 \%, 26,97 \%)$ dari pada sabut kelapa $(34,41 \%, 30,92 \%, 56,04 \%, 20,95 \%)$. Dalam hal kadar alfa-selulosa, tidak ada perbedaan nyata antara pelepah nipah $(29,75 \%)$ dan sabut kelapa $(30,92 \%)$. Untuk papan serat yang dikehendaki adalah bahan serat dengan kadar air rendah, kadar selulosa (juga alfaselulosa) dan kadar lignin tinggi, karena selulosa merupakan komponen utama serat, dan lignin berperan sebagai bahan pengikat alami pada pembentukan lembaran papan serat. Di samping itu, lignin pada bahan serat berligno-selulosa awal (kayu dan bahan serat lainnya) terkait erat dengan sifat kekakuan sel serat dan berperan sebagai bahan pengikat antar serat tersebut (Labosky, 1997; Haygreen dan Bowyer, 1999). Kadar pentosan dan hemiselulosa tinggi juga dikehendaki untuk memudahkan proses penggilingan pulp. Sebaliknya berat jenis, kadar abu dan silika yang tinggi; dan kelarutan dalam air dingin, dalam air panas, dalam alkohol-benzena, dan dalam alkali $1 \%$ yang tinggi tidak dikehendaki. Berat jenis dan kadar abu (silika) yang tinggi cenderung memerlukan kondisi pengolahan lebih keras, mengkonsumsi lebih banyak energi, cepat mempertumpul peralatan logam, dan berakibat negatif terhadap sifat fisik dan kekuatan MDF. Kelarutan dalam pelarut netral (air) dan pelarut organik (alkohol-benzena) berindikasi kandungan ekstraktif yang tinggi sehingga meningkatkan konsumsi bahan kimia pemasak, dan kelarutan dalam $\mathrm{NaOH} 1 \%$ selain terkait erat dengan kandungan ekstraktif juga berindikasi pada tingkat degradasi bahan serat berligno-selulosa, sehingga berpengaruh negatif terhadap sifat fisik/kekuatan pulp.

Untuk pelepah nipah, kadar ligninnya yang lebih rendah dibandingkan pada sabut kelapa, dan kelarutannya dalam pelarut netral (air), dalam pelarut organik (alkohol-benzena), dan dalam $\mathrm{NaOH} 1 \%$ yang lebih tinggi mengindikasikan bahwa serat pelepah nipah bersifat lebih polar, dan terindikasi memiliki porsi jaringan parenkhim yang lebih tinggi dibandingkan serat sabut kelapa, dan hal ini ikut berperan lebih tingginya kadar air pelepah nipah. Berdasarkan telaahan nilai total skor (TS, yang merupakan hasil manipulasi uji BNJ) terhadap sifat dasar (berat jenis dan komposisi kimia) bahan serat berligno-selulosa di mana masing-masing aspek sifat dasar terkait yang dikehendaki untuk produk MDF dibobot sama, ternyata TS untuk serat

pelepah nipah (46) lebih rendah dibandingkan TS sabut kelapa (52). Dengan demikian berdasarkan telaahan berat jenis dan komposisi kimia, sabut kelapa berindikasi lebih prospektif sebagai bahan baku pembuatan MDF.

\section{Dimensi serat dan nilai turunannya}

Analisa keragaman terhadap dimensi serat dan nilai turunannya menunjukkan bahwa perbedaan macam bahan serat berpengaruh nyata (F-hitung dengan $\mathrm{P}<0,05$ atau 0,01$)$, dan penelaahan lebih lanjut dengan uji $\mathrm{BNJ}(\mathrm{P}<0,05)$, menunjukkan bahwa panjang serat, tebal dinding serat, daya tenun, bilangan Muhlstep, dan bilangan Runkel, nilainya untuk nipah (berturut-turut $2710,4 \mu \mathrm{m}$, $2,43 \mu \mathrm{m}, 115,53 \mu \mathrm{m}, 36,08,0,26)$ lebih tinggi dari pada untuk sabut kelapa $(1543,38 \mu \mathrm{m}, 1,95 \mu \mathrm{m}$, $55,08,25,01,0,16)$. Nilai diameter serat, diameter lumen, dan koefisien kelemasan pada pelepah nipah $(24,24 \mu \mathrm{m}, 19,38 \mu \mathrm{m}, 0,80)$ lebih rendah dari pada sabut kelapa $(29,10 \mu \mathrm{m}, 25,20 \mu \mathrm{m}, 0,87)$. Keadaan di mana dinding serat yang lebih tipis dan diameter lumen lebih besar pada sabut kelapa dibandingkan dengan pada pelepah nipah memperkuat penjelasan sebelumnya mengapa berat jenis sabut kelapa $(0,18)$ lebih rendah dibandingkan dengan pelepah nipah $(0,21)$. Untuk pembentukan lembaran papan serat, bahan serat 
yang dikehendaki adalah yang berserat panjang; berdinding tipis; diameter lumen besar; kekakuan serat, bilangan Muhlstep, dan kekakuaan serat rendah; dan koefisien kelemasan dan daya tenun tinggi. Kesemua hal tersebut akan berpengaruh positif pada sifat menggepeng serat, fleksibilitas serat, dan struktur anyaman serat pada pembentukan lembaran papan serat.

Berdasarkan nilai total skor (TS), ternyata TS untuk serat pelepah nipah (31) juga lebih rendah dibandingkan TS sabut kelapa (35). Dengan demikian berdasarkan telaahan dimensi serat dan nilai turunan dimensinya, sabut kelapa berindikasi lebih prospektif sebagai bahan baku pembuatan MDF.

\section{B. Sifat Pengolahan Pulp}

Analisa keragaman terhadap sifat pengolahan pulp menunjukkan bahwa perbedaan macam bahan serat (pelepah nipah dan sabut kelapa) (S), konsentrasi alkali (A), dan interaksinya $\left(\mathrm{S}^{*} \mathrm{~A}\right)$ berpengaruh nyata ( $\mathrm{F}$-hitung dengan $\mathrm{P}<0,05$ atau $0,01)$, dan penelaahan lebih lanjut diteruskan pula dengan uji $\mathrm{BNJ}(\mathrm{P}<0,05)$.

\section{Rendemen pulp}

Rendemen pulp nipah (58,98-70,09\%) lebih rendah dibandingkan dengan rendemen pulp sabut kelapa $(75,33-76,03 \%)$. Mungkin ini disebabkan kadar lignin pada sabut kelapa $(34,41 \%)$ lebih tinggi dibandingkan pada nipah $(21,80 \%)$. Semakin tinggi konsentrasi alkali, cenderung menurunkan rendemen pulp (terutama dari pelepah nipah). Konsentrasi alkali yang makin tinggi akan lebih banyak melarutkan lignin dan mendegradasi selulosa. Untuk sabut kelapa, peningkatkan konentrasi alkali (4-12\%), tidak mengakibatkan perubahan rendemen pulp. Diduga ini ada kaitannya pula dengan kadar lignin sabut kelapa yang lebih tinggi dan juga kelarutannya dalam $\mathrm{NaOH} 1 \%$ yang lebih rendah $(21,49 \%$ terhadap $42,85 \%)$, yang mengindikasikan pula fraksi bahan polimer berantai pendek pada sabut kelapa lebih rendah. Seluruh rendemen pulp, kecuali rendemen pulp sabut nipah pada konsentrasi akali $12 \%$ (rendemen agak rendah yaitu $58,02 \%$ ), terletak pada selang rendemen yang umum diperoleh dari pengolahan pulp semi-kimia $(60-85 \%)$ (Casey, 1980). Diduga ini terjadi karena alkali sebanyak $12 \%$ tersebut selain lebih banyak melarutkan lignin dan selulosa, juga berakibat lebih intensif mendegradasi bahan bukan serat pada pelepah nipah (sel parenkhim).

\section{Derajat kehalusan pulp}

Dalam hal derajat kehalusan pulp, ternyata nilai untuk pulp nipah (550-690 ml CSF) lebih rendah dibandingkan untuk pulp sabut kelapa (610-705 $\mathrm{ml}$ CSF); dan waktu giling guna mencapai $600-700$ $\mathrm{ml}$ CSF untuk pulp nipah tersebut (50-55 menit) juga lebih singkat dari pada untuk pulp sabut kelapa (55-60 menit), yang mengindikasikan bahwa pulp nipah lebih mudah digiling dari pada pulp sabut kelapa. Ini terjadi karena kadar hemiselulosa pada pelepah nipah (26,97\%) lebih tinggi dari pada sabut kelapa (25,12\%); dan juga kadar lignin pada sabut kelapa lebih tinggi dibandingkan pada nipah. Semakin tinggi konsentrasi alkali hingga 12\%, maka derajat kehalusan pulp khususnya pulp nipah cenderung menurun lebih drastis mencapai $550 \mathrm{ml} \mathrm{CSF}$, dan waktu giling semakin singkat pula, sedangkan untuk pulp sabut kelapa penurunan tersebut hanya mencapai $640 \mathrm{ml} \mathrm{CSF}$ ), dan penurunan waktu giling tidak sebanyak untuk pulp pelepah nipah. Kemungkinan yang terjadi untuk pelepah nipah, alkali pada konsentrasi tersebut berakibat lebih banyak melarutkan lignin. Ini menyebabkan sifat hidrofilik pulp meningkat sehingga pulpnya mudah digiling. Selanjutnya, untuk sabut kelapa diduga kadar lignin yang tinggi dan kelarutan dalam $\mathrm{NaOH} 1 \%$ yang rendah tersebut berakibat delignifikasi lebih sulit dan mengindikasikan lagi bahwa tekstur sabut kelapa lebih padat, sehingga berakibat pulp sabut kelapa lebih sukar digiling. Ini menjelaskan bahwa walaupun diameter lumen sabut kelapa lebih besar dan dinding serat lebih tipis dibandingkan pada pelepah nipah (Tabel 4), akan tetapi kadar lignin sabut kelapa yang jauh lebih tinggi (Tabel 2) menyebabkan serat sabut kelapa lebih kaku. Seluruh derajat kehalusan pulp terletak pada selang yang umum untuk pembentukan papan serat termasuk MDF (600$700 \mathrm{ml}$ CSF) (Casey, 1980), kecuali pulp pelepah nipah pada konsentrasi akali 12\% (550 ml CSF). 
Adanya perbedaan nyata antara derajat kehalusan pulp pelepah nipah dengan pulp sabut kelapa, mengindikasikan bahwa pengolahan pulp campuran kedua macam bahan serat tidak layak dilakukan dalam satu kondisi proses. Kondisi yang lebih layak adalah pencampuran antar pulp pelepah nipah dengan pulp pelepah sabut kelapa pada proporsi tertentu, di mana masing-masing pulp tersebut diolah menggunakan kondisi perngolahan yang saling berbeda satu terhadap lainnya.

\section{Konsumsi alkali}

Konsumsi alkali meningkat drastis dengan peningkatan konsentrasi alkali (2,40-2,60\% menjadi 9,88-11,14\%). Konsumsi alkali selama pengolahan pulp pelepah nipah $(2,60-11,14 \%)$ cenderung lebih tinggi dibandingkan dengan selama pengolahan pulp sabut kelapa $(2,40-$ $9,88 \%$. Walaupun kadar lignin sabut kelapa nipah lebih tinggi dibandingkan pada pelepah nipah, diduga fenomena ini ada kaitannya dengan kelarutan dalam air dingin, air panas, alkoholbenzena, dan alkali $1 \%$ untuk pelepah nipah yang lebih tinggi dibandingkan untuk sabut kelapa. Fraksi terlarut tersebut berpotensi lebih banyak mengkonsumsi alkali.

\section{Telaahan keseluruhan sifat pengolahan pulp}

Secara umum sifat pengolahan pulp yang dikehendaki adalah rendemen pulp tinggi, konsumsi alkali rendah, dan derajat kehalusan pulp rendah pula ( $\mathrm{ml} \mathrm{CSF}$ ) atau waktu giling sesingkat mungkin, karena terkait dengan pemakaian energi. Hal tersebut dipakai sebagai dasar penentuan nilai total skor (TS) yang merupakan hasil manipulasi uji BNJ terhadap sifat pengolahan pulp tersebut, di mana masingmasing aspek sifat pengolahan terkait dibobot sama pula. Ternyata untuk pelepah nipah yang paling berprospektif menjadi pulp pada konsentrasi akali $4 \%(\mathrm{TS}=13)$, sedangkan untuk sabut kelapa adalah pada konsentrasi $4 \%$ dan $8 \%$ (TS =13). Secara keseluruhan, baik sabut kelapa ataupun pelepah nipah sama-sama dapat diolah menjadi pulp MDF, tetapi prospek sabut kelapa relative lebih tinggi.

\section{Sifat Fisis dan Mekanis Papan Serat Tipe MDF}

Analisa keragaman terhadap sifat fisis dan mekanis MDF (kadar air, kerapatan, keteguhan lentur, keteguhan patah, keteguhan rekat internal, penyerapan air, pengembangan tebal, daya hantar panas, dan ketahanan panas) menunjukkan bahwa pengaruh konsentrasi alkali (A), proporsi campuran antara pulp pelepah nipah dengan pulp sabut kelapa (B), dan penggunaan bahan perekat UF dan arang aktif (C), interaksi ke tiga faktor tersebut $\left(A^{*} B^{*} C\right)$ berpengaruh nyata (F-hitung dengan $\mathrm{P}<0,05$ atau 0,01$)$; dan penelahan lebih lanjut dengan uji $\mathrm{BNJ}(\mathrm{P}<0,05)$.

\section{Kadar air}

Berdasarkan uji BNJ, kadar air papan MDF cenderung menurun dengan meningkatnya konsentrasi alkali $(14,73 \%$ menjadi $14,09 \%)$. Alkali pada konsentrasi tersebut menyebabkan degradasi dan pelarutan lignin lebih intensif menjadi polimer berantai lebih pendek dan berat molekul rendah. Diduga sebagian polimer tersebut teradsorpsi dan terabsorpsi ke dalam struktur serat ligno-selulosa, dan sebagai akibatnya menutupi gugusan-gugusan polar pada rantai selulosa. Hal tersebut berakibat sifat higroskopis papan MDF menjadi lebih rendah. Atas dasar uji BNJ, peningkatan porsi pulp sabut kelapa terhadap porsi pulp pelepah nipah juga cenderung menurunkan kadar air tersebut. Diduga ini terkait dengan lebih tingginya kadar lignin dan lebih sedikitnya porsi jaringan parenkhim dalam sabut kelapa (diindikasikan dari rendahnya kelarutan dalam air panas dan alkali $1 \%$, sehingga mengurangi polaritasnya) dibandingkan dengan pada pelepah nipah. Dugaan lain adalah pulp pelepah nipah lebih mudah digiling dari pada pulp sabut kelapa, dan ini memperkuat indikasi bahwa pulp pelepah nipah lebih mudah terfibrilisasi sehingga sifatnya lebih higroskopis.

Hasil uji BNJ menunjukkan bahwa penggunaan bahan perekat UF, dan penggunaannya dikombinasikan dengan arang aktif, cenderung menurunkan pula kadar air papan MDF dibandingkan dengan kontrol (papan serat tanpa UF dan arang aktif) (14.,46-14,65\% 
terhadap $14,06 \%$ ). Diduga penggunaan perekat UF (sebelum dan mendekati tahap curing) banyak membantu ikatan antar serat melalui reaksi kondensasi dengan gugusan fungsionil dengan lignin dan mungkin juga dengan selulosa pada permukaan serat (Blomquist et al., 1981; Suchsland dan Woodson, 1986; Ebnesajjad, 2008; Wikipedia, 2012b). Hal tersebut banyak menutup gugusan polar ( $\mathrm{OH}$ bebas khususnya) sehingga menurunkan sifat higroskopis serat pada saat lembaran MDF terbentuk. Pada kombinasinya dengan arang aktif, diduga karena arang tersebut berupa partikel kecil menyebabkan luas permukaan bertambah besar. Akibatnya air yang terdapat dalam serat pulp teradsorpsi oleh arang tersebut, dan air tersebut selanjutnya menguap pada saat papan MDF mengalami perlakuan panas. Ini mengakibatkan kombinasinya dengan arang aktif tersebut, lebih menurunkan lagi kadar air papan MDF $(14,46 \%$ terhadap $14,65 \%$. Secara umum kadar air pada MDF yang dikehendaki adalah serendah mungkin, sebab akan mengurangi berat, mempertinggi keawetan dan meningkatkan ketahanan terhadap serangan organisme, dan memudahkan pengerjaan selanjutnya (PT Masari Dwisepakat Fiber, 2009;
ISO/DIS, 2009b). Kadar air papan MDF berkisar 11,56-16,19\%, dan sebagian besar (Tabel 1) tidak memenuhi persyaratan JIS, yaitu $5-13 \%$ (JIS, 2003).

\section{Kerapatan}

Peningkatan konsentrasi alkali juga cenderung meningkatkan kerapatan papan MDF yang terbentuk yaitu 0,62 menjadi $0,73 \mathrm{~g} / \mathrm{cm}^{3}$ (F-hitung dengan $\mathrm{P}<0,01)$. Diduga peningkatan konsentrasi tersebut berakibat delignifikasi bahan serat baik pelepah nipah ataupun sabut kelapa semakin intensif. Ini menyebabkan fleksibilitas bahan serat meningkat. Menurut Haygreen dan Bowyer (1999) lignin berperan nyata terhadap kekakuan bahan serat berligno-selulosa. Akibatnya dengan berkurangnya kandungan lignin, maka serat mudah menggepeng dan ikatan antar serat menjadi lebih kompak (rapat).

Berdasarkan uji BNJ $(\mathrm{P}<0,05)$, diketahui peningkatan porsi campuran pulp sabut kelapa terhadap pulp nipah $(50 \%+50 \%)$ tidak mengakibatkan perubahan kerapatan papan MDF yang terbentuk $\left(0,675\right.$ terhadap $\left.0,679 \mathrm{~g} / \mathrm{cm}^{3}\right)$. Papan MDF dari pulp sabut kelapa 100\% (tanpa campuran dengan pulp pelepah nipah),

Tabel1. Data sifat fisik - mekanis dan emisi formaldehida papan serat kerapatan rendah Table 1. Data on physical-mechanical properties of medium-density fiberboard

\begin{tabular}{|c|c|c|c|c|c|c|c|}
\hline \multirow{2}{*}{$\begin{array}{c}\text { Sifat } \\
\text { (Properties) }\end{array}$} & \multicolumn{3}{|c|}{$\begin{array}{l}\text { Serat pelepah nipah } \\
\text { (Nypha-midrib fibers) }\end{array}$} & \multicolumn{3}{|c|}{$\begin{array}{l}\text { Serat sabur kelapa } \\
\text { (Coconut-coir fibers) }\end{array}$} & \multirow{2}{*}{$\begin{array}{l}\text { Persyaratan } \\
\text { JIS (JLS } \\
\text { specifi-cation })^{\circ}\end{array}$} \\
\hline & I & II & III & I & II & III & \\
\hline Kerapatan/Density $\left(\mathrm{g} / \mathrm{cm}^{3}\right), \mathrm{Y}$ & $0,658-0,799$ & $0,623-0,763$ & $0,573-0,684$ & $0,628-0,731$ & $0,598-0,692$ & $0,578-0,726$ & $0,35-0,80$ \\
\hline $\mathrm{MC}(\%), \mathrm{Y}$ & $15,29-15,60$ & $14,97-17,30$ & $14,74-15,88$ & $11,56-13,19$ & $12,28-13,50$ & $13,66-14,39$ & 5-13 \\
\hline MOE $\left(\mathrm{kg} / \mathrm{cm}^{2}\right), \mathrm{Y}$ & $7613-10163$ & $7264-11878$ & $7092-7547$ & $4026-5905$ & $3324-6855$ & $3164-6503$ & $\geq 20260$ \\
\hline $\mathrm{MOR}, \mathrm{kg} / \mathrm{cm}^{2}, \mathrm{Y}$ & $85,7-86,3$ & $98,0-143,0$ & $82,9-101,0$ & $77,6-132,2$ & $58,7-136,7$ & $63,3-141,6$ & $\geq 255$ \\
\hline $\begin{array}{l}\text { Keteguhan internal /IB } \\
\left(\mathrm{kg} / \mathrm{cm}^{2}\right), \mathrm{Y}\end{array}$ & $0,87-2,14$ & $1,10-2,82$ & $1,03-1,86$ & $0,39-2,73$ & $0,79-4,60$ & $0,51-1,51$ & $\geq 2,0$ \\
\hline WA $(\%), Y$ & $121,1-151,5$ & $115,9-123,2$ & $115,9-133,1$ & $99,6-113,9$ & $87,45-108,0$ & $109,5-126,4$ & \\
\hline $\mathrm{TS}(\%), \mathrm{Y}$ & $21,39-36,65$ & $18,62-47,60$ & $25,43-56,60$ & $21,77-28,74$ & $21,51-30,20$ & $21,95-34,27$ & $\geq 12$ \\
\hline $\mathrm{HC}\left(\mathrm{W} \mathrm{m}^{-1} \cdot \mathrm{K}^{-1}\right), \mathrm{Y}$ & $0,092-0,104$ & $0,087-0,101$ & $0,072-0,087$ & $0,082-0,097$ & $0,068-0,086$ & $0,067-0,071$ & \\
\hline $\mathrm{TR}\left(\mathrm{m}^{2} \mathrm{~K} . \mathrm{W}{ }^{-1}\right), \mathrm{Y}$ & $0,107-0,129$ & $0,109-0,146$ & $0,127-0,167$ & $0,124-0,134$ & $0,134-0,140$ & $0,155-0,166$ & \\
\hline $\mathrm{FE}(\mathrm{mg} / \mathrm{L})$ & $3,96-4,30$ & $1,88-8,75$ & $0,13-0,37$ & $0,55-8,06$ & $4,89-8,78$ & $0,22-0,47$ & $\geq 1,5$ \\
\hline Y-discr & $74,1-101,1$ & $72,3-94,5$ & $68,2-90,3$ & $49,4-70,4$ & $48,3-69,2$ & $47,2-65,7$ & \\
\hline
\end{tabular}

Keterangan (Remarks): I = dengan aditif (perekat UF 5\%+arang aktif 5\%+ alum 4\% / with additives (UF adbesive 5\%+activated charcoal $5 \%+$ alum 4\%); II = dengan aditif (perekat UF5\% + alum 4\%) / with additives $(U F$ adhesive $5 \%+$ alum 4\%); $\mathrm{III}=$ control (tanpa aditif) / control (without additives); $\mathrm{MC}=\mathrm{kadar}$ air $/$ moisture content; IB = keteguhan internal / internal bond; WA = penyerapan air / water absorption; $\mathrm{TS}=$ pengembangan tebal $/$ thickeness swelling, $\mathrm{HC}=$ daya hantar panas / beat conductivity; TR = ketahanan panas thermal resistance; $\mathrm{FE}=$ emisi formaldehida / formaldebyde emission; Y-discr (nilai diskriminan / adiscriminant value) $=+57.09$ Y1 -55.12 Y2 +24.56 Y3 +36.39 Y4 + 33.00 Y5 - 1.61 Y6 -31,68 Y7 -46,98 Y8 + 100,52 Y9 -100,54 Y10, dengan koef. Determinasi kanonik nyata / with significant canonic determination coeff. (R2=0,962**), yang menunjukkan tingkat peranan absolute masing-masing-masing sifat dari yang terbesar hingga terkecil/ which revealed the absolute significances of each property consecutively from the bighest to the lowest (i.e. $\mathrm{Y} 10>\mathrm{Y} 9>\mathrm{Y} 1>\mathrm{Y} 2>\mathrm{Y} 8>\mathrm{Y} 4>\mathrm{Y} 5>\mathrm{Y} 7>\mathrm{Y} 3>\mathrm{Y} 6) ; "$ JIS $(2003)$ 
kerapatannya lebih rendah dari pada yang dicampur dengan pulp pelepah nipah $(0,670$ terhadap $\left.0,679 \mathrm{~g} / \mathrm{cm}^{3}\right)$. Ini berindikasi bahwa tekstur serat pulp sabut kelapa lebih kaku dan juga lebih sukar digiling dibandingkan dengan serat pulp (Tabel 6).

Penggunaan perekat UF cenderung meningkatkan kerapatan papan MDF, sebagaimana diindikasikan dari hasil uji $\mathrm{BNJ}$ $\left(0,684-0,697\right.$ terhadap $\left.0,649 \mathrm{~g} / \mathrm{cm}^{3}\right)$. Diduga perekat tersebut membantu mengintensifkan ikatan serat-perekat dan ikatan serat-serat, sehingga menurunkan volume rongga kosong antara serat saat pembentukan lembaran MDF. Penggunaan perekat UF dikombinasikan dengan arang aktif lebih meningkatkan lagi kerapatan papan MDF (0,697 terhadap $\left.0,684 \mathrm{~g} / \mathrm{cm}^{3}\right)$. Kemungkinan yang terjadi arang aktif merupakan partikel kecil sehingga banyak mengisi ruang kosong antar serat dalam struktur MDF, sehingga meningkatkan kerapatannya. Secara umum, MDF yang dikehendaki adalah memiliki kerapatan tinggi, karena berpengaruh positif pada sifat fisik dan mekaniknya (ISO/DIS, 2009). Keseluruhan kerapatan MDF berkisar 0,573$0,799 \mathrm{~g} / \mathrm{cm}^{3}$ (Tabel 1), dan hampir seluruhnya memenuhi persyaratan JIS, yaitu $0,35-0,80 \mathrm{~g} / \mathrm{cm}^{3}$ (JIS, 2003).

\section{Keteguhan lentur}

Keteguhan lentur (MOE) papan MDF meningkat dengan meningkatnya konsentrasi alkali $\left(5334,92\right.$ menjadi $\left.7721,50 \mathrm{~kg} / \mathrm{cm}^{2}\right)$. Hal ini dapat dipahami karena alkali menyebabkan delignifikasi bahan serat lebih intensif dan selanjutnya mengakibatkan serat pulp lebih fleksibel. Ini berpengaruh positif pada ikatan antar serat pada saat pembentukan lembaran MDF, sehingga kekuatannya meningkat. Uji BNJ $(\mathrm{P}<0.05)$ juga mengindikasikan bahwa peningkatan porsi campuran pulp sabut kelapa terhadap porsi pulp pelepah nipah berakibat penurunan MOE papan MDF $(8450,22$ menjadi $\left.5267,11 \mathrm{~kg} / \mathrm{cm}^{2}\right)$. Hal ini mungkin disebabkan oleh tekstur serat sabut kelapa cenderung lebih kaku dibandingkan serat nipah; selain itu pulp sabut kelapa lebih sukar digiling dari pada pulp pelepah nipah. Serat pelepah nipah yang lebih panjang dibandingkan serat sabut kelapa diduga juga ikut berperan terhadap fenomena tersebut. Akibatnya, ikatan antar serat di dalamnya kurang sempurna pada saat pembentukan lembaran MDF. Di samping itu lebih rendahnya daya tenun serat sabut kelapa dibandingkan dengan pada serat pelepah nipah $(55,08$ terhadap 115,53$)$ diduga ikut berperan secara negatif terhadap ikatan antar serat saat pembentukan lembaran MDF, sehingga kekuatannya menurun.

Di lain hal, penambahan perekat UF pada serat pulp mengakibatkan MOE MDF meningkat $\left(6347,75\right.$ menjadi $\left.6930,67-7233,92 \mathrm{~kg} / \mathrm{cm}^{2}\right)$. Ini dapat dimengerti karena perekat UF membuat ikatan serat-serat lebih intensif sehingga berpengaruh positif pada kerapatan MDF. Berdasarkan uji $\mathrm{BNJ}$, penggunaan perekat UF yang dikombinasikan dengan arang aktif ternyata menurunkan MOE MDF dibandingkan dengan yang tanpa arang aktif 6930,67 terhadap 7233,92 $\left.\mathrm{kg} / \mathrm{cm}^{2}\right)$. Hal ini mengindikasikan arang aktif dalam bentuk partikel kecil mengganggu ikatan dalam MDF. Secara umum, MDF yang dikehendaki memiliki MOE setinggi mungkin (ISO/DIS, 2009b). Keseluruhan MOE MDF hasil percobaan (Tabel 1) tidak memenuhi persyaratan JIS, yaitu $20260 \mathrm{~kg} / \mathrm{cm}^{2}$ (JIS , 2003).

\section{Keteguhan patah}

Keteguhan patah (MOR) papan MDF cenderung meningkat dengan semakin tinggi konsentrasi alkali $\left(71,96\right.$ menjadi $\left.115,99 \mathrm{~kg} / \mathrm{cm}^{2}\right)$. Fenomena ini berindikasi serupa dengan yang terjadi pada MOE. Secara rata-rata, MDF dari pulp pelepah nipah $100 \%$ menunjukkan MOR tertinggi $\left(108,36 \mathrm{~kg} / \mathrm{cm}^{2}\right)$ dan berdasarkan uji BNJ $(\mathrm{P}<0,05)$, MOR cenderung menurun hingga penambahan porsi pulp sabut kelapa $50-100 \%\left(98,45 \mathrm{~kg} / \mathrm{cm}^{2}\right)$. Gejala ini juga seperti yang terjadi sebelumnya pada MOE MDF. Namun demikian, hasil uji BNJ ternyata penggunaan perekat UF tidak mempengaruhi MOR MDF dibandingkan dengan MOR MDF kontrol. Uji BNJ lebih lanjut menunjukkan bahwa penggunaan perekat UF yang dikombinasikan dengan arang aktif mengakibatkan penurunan MOR dibandingkan dengan MOR MDF yang diberi perekat UF (tanpa arang aktif) ataupun 
MOR MDF kontrol (tanpa UF dan arang aktif). Diduga, arang aktif tersebut menyebabkan gangguan ikatan serat dalam MDF sehingga menurunkan MORnya. Secara umum, MOR MDF yang dikehendaki adalah setinggi mungkin. Selanjutnya, seluruh MOR MDF hasil percobaan (Tabel 1) tidak memenuhi persyaratan JIS, yaitu $255 \mathrm{~kg} / \mathrm{cm}^{2}$ (JIS, 2003).

\section{Keteguhan rekat internal}

Keteguhan rekat internal (IB) MDF mula-mula meningkat dengan meningkatnya konsentrasi alkali dari $4 \%$ menjadi $8 \%$, dan selanjutnya menurun dengan peningkatan konsentrasi tersebut menjadi $12 \%$ (1,051 menjadi berturutturut 2,057 dan $\left.1,780 \mathrm{~kg} / \mathrm{cm}^{2}\right)$. Peningkatan konsentrasi akali melewati $8 \%$ hingga mencapai $12 \%$ selain lebih mengintensifkan delignifikasi ternyata juga mengakibatkan degradasi polimer rantai selulosa pada serat tersebut. Akibatnya kekuatan individu serat pulp menurun (Casey, 1980;ISO/DIS, 2009). Lebih lanjut, hasil uji BNJ $(\mathrm{P}<0,05)$ menunjukkan bahwa semakin tinggi porsi campuran pulp sabut kelapa terhadap porsi pulp pelepah nipah mengakibatkan penurunan IB $\left(1,88\right.$ menjadi $\left.1,63 \mathrm{~kg} / \mathrm{cm}^{2}\right)$. Berdasarkan uji BNJ ternyata IB MDF yang diberi perekat UF tidak berbeda nyata dengan IB MDF kontrol (1.91 terhadap $1,87 \mathrm{~kg} / \mathrm{cm}^{2}$ ). Keteguhan rekat internal (IB) MDF dengan perekat UF yang dikombinasikan dengan arang aktif lebih rendah dibandingkan IB MDF dengan perekat UF sendiri $\left(1,85\right.$ terhadap $\left.1,91 \mathrm{~kg} / \mathrm{cm}^{2}\right)$. Fenomena tersebut di atas terindikasi serupa pada MOR. Secara umum, IB MDF yang dikehendaki adalah setinggi mungkin. Dibandingkan dengan persyaratan IB MDF menurut JIS yatu $2,00 \mathrm{~kg} / \mathrm{cm}^{2}$ (JIS, 2003), maka hanya sebagian kecil dari MDF hasil percobaan (Tabel 1) yang memenuhi syarat

\section{Daya hantar panas dan ketahanan panas}

Daya hantar panas (thermal conductivity) mula-mula meningkat lalu menurun dengan meningkatnya konsentrasi alkali dari 4\% $(0,08491$ W. $\left.\mathrm{m}^{-1} \cdot \mathrm{K}^{-1}\right)$, ke $8 \%\left(0.0897 \mathrm{~W} \cdot \mathrm{m}^{-1} \cdot \mathrm{K}^{-1}\right)$, hingga $12 \%$ $\left(0,0782 \mathrm{~W} \cdot \mathrm{m}^{-1} \cdot \mathrm{K}^{-1}\right)$ sebagaimana diindikasikan dari uji BNJ $(\mathrm{P}<0,05)$. Ketahanan panas (heat resistance) berbanding terbalik dengan daya hantar panas (Wikipedia, 2012). Diduga peningkatan daya hantar panas tersebut terkait dengan delignifikasi yang makin intensif akibat peningkatan konsentrasi alkali (4-8\%) sehingga membuat bahan serat lebih fleksibel, yang selanjutnya berakibat ikatan serat selama pembentukan MDF menjadi lebih kompak.. Hal tersebut mengakibatkan volume rongga-rongga udara dalam MDF menurun, sehingga daya hantar panasnya meningkat (ketahanan panas menurun). Di lain hal, peningkatan konsentrasi alkali dari 8\% menjadi $12 \%$, berakibat lebih banyak lignin yang terlarut. Unsur karbon $(\mathrm{C})$ pada senyawa organik sangat berperan terhadap daya hantar panasnya, dibandingkan unsur lain seperti hidrogen $(\mathrm{H})$, oksigen, $(\mathrm{O})$, dan nitrogen $(\mathrm{N})$, di mana daya hantar panas $C$ sebesar 25470 W.m-1.K-1 (Chemical, 2004). Kadar C pada selulosa adalah $44,44 \%$, sedangkan pada lignin $67,50 \%$ (Browning, 1967; Casey, 1980). Agaknya pada konsentrasi alkali $12 \%$, porsi lignin pada serat pulp lebih banyak telarut dibandingkan porsi selulosa sehingga banyak menurunkan kadar C. Fenomena inipun diduga ada kaitannya dengan menurunnya daya hantar panas MDF dengan meningkatnya konsentrasi alkali.

Berdasarkan hasil uji BNJ $(\mathrm{P}<0,05)$, peningkatan porsi pulp sabut kelapa hingga $50 \%$ terhadap porsi pulp pelepah nipah ternyata tidak mengakibatkan perubahan nyata daya hantar panas papan MDF yang terbentuk $(0,0888$ menjadi $\left.0,0872 \mathrm{~W} \cdot \mathrm{m}^{-1} \cdot \mathrm{K}^{-1}\right)$. Akan tetapi MDF yang dibentuk dari pulp sabut kelapa 100\% memiliki daya hantar panas terendah $(0,0789 \mathrm{~W} . \mathrm{m}$ $\left.{ }^{1} \cdot \mathrm{K}^{-1}\right)$. Mungkin ini ada kaitannya dengan rendahnya kerapatan MDF dari pulp sabut kelapa $100 \%$, yang berakibat volume rongga udara dalam MDF cenderung besar, sehingga daya hantar panas menurun.

Uji BNJ juga mengindikasikan bahwa nilai daya hantar panas MDF yang diberi perekat UF lebih tinggi dibandingkan nilai untuk MDF kontrol (tanpa bahan perekat) (0,0859-0,0912 terhadap $\left.0,0782 \mathrm{~W} \cdot \mathrm{m}^{-1} \cdot \mathrm{K}^{-1}\right)$. Diduga kuat ini terkait pula dengan kerapatan MDF yang lebih tinggi dibandingkan dengan MDF kontrol (volume rongga udara menurun), sehingga daya hantar panas MDF meningkat. Lebih lanjut, daya hantar 
panas papan MDF dengan perekat UF yang dikombinasikan dengan penambahan arang aktif $(0,0912)$, berdasarkan uji BNJ ternyata lebih tinggi lagi dibandingkan dengan MDF dengan perekat UF saja $\left(0,0859 \mathrm{~W} \cdot \mathrm{m}^{-1} \cdot \mathrm{K}^{-1}\right)$. Mungkin ini terkait dengan kadar $\mathrm{C}$ pada arang aktif relatif tinggi (80\%) (Saptadi, 2009). Papan MDF yang dikehendaki adalah memiliki daya hantar panas rendah atau ketahanan panas tinggi, karena sesuai dengan salah satu fungsinya yaitu sebagai penyekat panas.

\section{Penyerapan air}

Berdasarkan hasil uji BNJ $(\mathrm{P}<0,05)$, penyerapan air cenderung menurun dengan peningkatan konsentrasi alkali dari $4 \%$ menjadi $12 \%$ (118,75\% menjadi $115,29 \%)$. Semakin tinggi porsi campuran pulp sabut kelapa terhadap porsi pulp pelepah nipah, maka penyerapan air MDF dihasilkan cenderung menurun pula $(128,41 \%$ menjadi $108.21 \%)$. Fenomena ini terindikasi serupa dengan kadar air MDF.

Uji BNJ menunjukkan bahwa penyerapan air MDF dengan perekat UF lebih rendah dibandingkan MDF kontrol (107,59-116,18\% terhadap $127.57 \%$ ). Fenomena ini terjadi pula pada sifat kekuatan pulp (MOE dan IB). Produk MDF yang diberi perekat UF dan dikombinasikan dengan arang aktif $(116,18 \%)$ menunjukkan penyerapan air yang lebih tinggi dibandingkan MDF dengan UF saja $(107,59 \%)$. Fenomena ini serupa dengan yang terjadi pada kadar air MDF (Tabel 8). Penyerapan air MDF (dengan UF dan arang aktif) ternyata masih lebih rendah dibandingkan dengan MDF kontrol (tanpa UF dan arang aktif). Produk MDF yang dikehendaki adalah memiliki penyerapan air serendah mungkin, karena ada kaitan erat dengan kestabilan dimensi papan serat dan ketahanannya terhadap serangan organisme dan degradasi.

\section{Pengembangan tebal}

Pengembangan tebal MDF berdasarkan hasil uji $\mathrm{BNJ}(\mathrm{P}<0,05)$ cenderung menurun dengan peningkatan konsentrasi alkali selama pemasakan pulp (40,33\% menjadi $23,20 \%)$. Fenomena ini sejalan dengan yang terjadi pada penyerapan air. Peningkatan porsi campuran pulp sabut kelapa terhadap pulp pelepah nipah mengakibatkan penurunan pada pengembangan tebal $(34,99 \%$ menjadi 26,54\%). Hal inipun sejalan dengan penyerapan air. Menurunnya penyerapan air berarti lebih sedikit molekul air yang memasuki struktur serat MDF, dengan demikian potensi pengembangannya menurun pula. Di samping itu berat jenis/kerapatan dan tebal dinding serat sabut kelapa yang lebih rendah dibandingkan dengan pelepah nipah (berturut-turut $0,18 \mathrm{~g} / \mathrm{cm}^{3}$ dan $1,95 \mu \mathrm{m}$ terhadap $0,21 \mathrm{~g} / \mathrm{cm}^{3}$ dan $2,43 \mu \mathrm{m}$ ) berperan pula terhadap lebih rendahnya pengembangan tebal MDF tersebut pada porsi campuran pulp sabut kelapa yang semakin besar. Berat jenis dan tebal dinding serat bahan berlignoselulosa berkorelasi positif dengan pengembangan tebalnya (Haygreen dan Bowyer, 1999).

Uji BNJ menunjukkan pula bahwa pengembangan tebal MDF dengan perekat UF $(30,13-30,56 \%)$ lebih rendah dibandingkan dengan pada MDF kontrol (34,82\%). Fenomena ini serupa dengan penyerapan air. Lebih lanjut, MDF yang diberi perekat UF dan dikombinasikan dengan arang aktif menunjukkan pengembangan tebal yang sedikit lebih rendah dibandingkan MDF dengan UF saja (30,13\% terhadap 30,56\%). Fenomena ini berlawanan dengan penyerapan air yang cenderung meningkat $(116,18 \%$ terhadap $107,59 \%)$. Kemungkinan yang terjadi adalah partikel arang aktif bersifat polar dan juga memiliki luas permukaan yang besar. Ini mengakibatkan molekul air banyak teradsorpsi oleh arang aktif dan lebih sedikit yang memasuki struktur serat MDF. Dengan demikian walaupun penyerapan air meningkat MDF, pengembangan tebalnya menurun.

Sama halnya dengan penyerapan air, MDF yang dikehendaki adalah memiliki pengembangan tebal serendah mungkin, karena terkait dengan kestabilan dimensi papan serat. Pengembangan tebal MDF hasi percobaan (Tabel 1), dibandingkan dengan persyaratan JIS yaitu $12.0 \%$ (JIS, 2003) ternyata seluruhnya tidak memenuhi syarat.

\section{Emisi Formaldehida}

Analisis keragaman terhadap emisi formaldehida MDF menunjukkan bahwa 
pengaruh konsentrasi alkali (A), proporsi campuran antara pulp pelepah nipah dengan pulp sabut kelapa (B), dan penggunaan bahan perekat UF dan arang aktif $(\mathrm{C})$, berikut interaksi ke tiga faktor tersebut $\left(\mathrm{A}^{*} \mathrm{~B} * \mathrm{C}\right)$ masing-masing berpengaruh nyata ( $\mathrm{F}$-hitung dengan $\mathrm{P}<0,01)$

Emisi formaldehida berdasarkan uji BNJ ternyata meningkat pada peningkatan konsentrasi alkali dari $4 \%$ ke $8 \%$ selama pengolahan pulp (2,32 menjadi $3,42 \mathrm{mg} / \mathrm{L}$ ), dan selanjutnya peningkatan konsentrasi hingga 12\% tidak mengakibatkan perubahan nyata terhadap emisi tersebut $(3,36$ $\mathrm{mg} / \mathrm{L}$ ). Ada dua kemungkinan argumentasi untuk menjelaskan fenomena tersebut. Argumentasi pertama adalah menurunnya kandungan lignin dalam serat pulp akibat degradasi dan pemutusan rantai oleh alkali hingga terlarut ke dalam larutan pemasak soda. Akibatnya kemampuan lignin (sebagai polifenol) pada serat pulp untuk mengikat formaldehida $(\mathrm{HCOH})$ bebas menurun (Tsoumi, 1993; Santoso, 2000; 2011; IPIRTI, 2012), dan konsekuensinya porsi $\mathrm{HCOH}$ bebas dalam MDF meningkat (Smook and Kocurek, 1993). Argumentasi ke dua adalah lignin yang terfragmentasi menjadi bentuk rantai pendek (berat molekul rendah) dan masuk ke dalam larutan pemasak soda selanjutnya akan mengalami redeposition atau reabsorption pada struktur serat pulp (terbawa bersama pulp) (Casey, 1980). Semakin meningkat konsentrasi alkali, maka semakin banyak lignin yang terdeposition/ reabsorption pada serat pulp. Pada saat pulp dibentuk menjadi lembaran MDF di mana terdapat perlakuan panas (heat treatment) dan pengempaan panas (hot pressing) menggunakan suhu di atas $100^{\circ} \mathrm{C}$, lignin tersebut kemungkinan besar mengalami karbonisasi parsial (charring) menghasilkan gas-gas dengan berat molekul rendah seperti karbon monoksida (CO), hidrogen (H2), dan HCHO (Sjostrom, 1993; ISO/DIS, 2009; Sazanov dan Gribanov, 2010). Jadi untuk argumentasi ke dua, emisi $\mathrm{HCHO}$ tidak saja berasal dari UF tetapi dari lignin pada serat MDF. Agaknya untuk kasus peningkatan konsentrasi alkali, fenomena argumentasi pertama lebih mendominir terhadap argumentasi kedua.

Peningkatan porsi campuran pulp sabut kelapa terhadap pulp nipah cenderung pula meningkatkan emisi formaldehida (1,74 menjadi 3,31 mg/L).
Diduga fenomena ini lebih sejalan dengan argumentasi ke dua tersebut, di mana kadar lignin sabut kelapa lebih tinggi dibandingkan pelepah nipah (Tabel 2). Keadaan ini memperbesar peluang terbentuknya $\mathrm{HCOH}$ akibat charring pada lignin khususnya pada tahapan heat treatment dan hot pressing.

Uji BNJ $(\mathrm{P}<0,05)$ menunjukkan bahwa emisi formaldehida MDF yang dibentuk menggunakan perekat UF jauh lebih tinggi dibandingkan dengan MDF kontrol (3,74-4,16 terhadap 0,21 mg/L). Lebih lanjut, emisi formaldehida MDF yang dibentuk dengan UF tetapi melibatkan penambahan arang aktif cenderung menurun (3,74 $\mathrm{mg} / \mathrm{L})$ dibandingkan pada MDF dengan UF saja (tanpa arang aktif) (4,16 mg/L). Ini membuktikan arang aktif yang bersifat polar dan memiliki luas permukaan yang besar yang berperan mengadsorpsi dan mengurangi emisi formaldehida akibat penggunaan UF. Emisi MDF yang dibentuk menggunakan perekat berbasis formaldehida (termasuk UF) dikehendaki seminimal mungkin. Emisi MDF hasil percobaan (Tabel 1) sebagian besar tidak memenuhi persyaratan JIS (JIS, 2003) yaitu $\leq 1.5 \mathrm{~m} / \mathrm{L}$.

\section{E. Telaahan Sifat Fisis - Mekanis MDF dan Emisi Formaldehida}

Penelaahan ini dilakukan dengan mencermati sifat MDF terkait, yang dipakai sebagai dasar penelahan dengan sistim skor dan dengan analisis diskriminan, guna menentukan kombinasi perlakuan mana yang dapat digunakan untuk memperoleh sifat MDF paling memuaskan.

Telaahan dengan sistim skor terhadap sifat fisik dan mekanik MDF dengan melibatkan aspek emisi formaldehida (Tabel 1) menunjukkan bahwa kombinasi perlakuan otimum adalah MDF dari campuran pulp pelepah nipah $50 \%$ dan pulp sabut kelapa $50 \%$, dengan konsentrasi alkali $4 \%$, dan tanpa pengunaan UF ataupun arang aktif (TS = 41.5), dan MDF dari pulp sabut kelapa $100 \%$, pada konsentrasi alkali $12 \%$, tanpa UF ataupun arang aktif (TS $=41,5$ ); diikuti oleh MDF dari pulp pelepah nipah $100 \%$, pada konsentrasi alkali $12 \%$, dengan penggunaan UF $3 \%(\mathrm{TS}=41$ ); dan oleh MDF dari pulp sabut kelapa $100 \%$, pada konsentrasi alkali $8 \%$, dengan perekat UF 
(TS =40,5). Ternyata telaahan tersebut mengindikasikan bahwa serat sabut kelapa masih berprospek lebih baik untuk MDF dibandingkan dengan serat pelepah nipah.

Di lain hal, hasil telaahan dengan analisis diskriminan terhadap sifat fisis dan mekanis MDF (Tabel 1) berikut aspek terkait (masing-masing aspek sifat yang diamati dibobot tidak sama) yang mencakup berat jenis (Y1), kadar air (Y2), MOE (Y3), MOR (Y4), IB (Y5), penyerapan air (Y6), pengembangan tebal (Y7), daya hantar panas (Y8), ketahanan panas (Y9), dan emisi formaldehida (Y10), dihubungkan dengan kriteria determinan/nilai mutu produk MDF (Y) menghasilkan persamaan $\mathrm{Y}=+57,09 \mathrm{Y} 1-55,12$ $\mathrm{Y} 2+24,56 \mathrm{Y} 3+36,39 \mathrm{Y} 4+32,99 \mathrm{Y} 5-1,61 \mathrm{Y} 6-$ 31,68 Y $7-46,98$ Y8 +100,52 Y9 $-100,54$ Y10 (Y1, Y2, Y3, ..., hingga Y10, dalam bentuk bentuk sudah dibakukan) dengan koefisien determinasi kanonik nyata diperoleh $\mathrm{R}^{2}=0,962^{* *}$ (Tabel 8). Apakah perlu desimal sebanyak itu, sebaiknya 2 desimal sudah cukup.

Dari persamaan diskriminan tersebut dapat dihitung nilai mutu produk MDF (Y) yang mengindikasikan bahwa serat pelepah nipah lebih berprospek untuk MDF dibandingkan serat sabut kelapa (setelah keduanya diolah menjadi pulp) dengan rincian untuk MDF dari pulp pelepah nipah $100 \%$ pada konsentrasi alkali $4-12 \%$, memiliki selang nilai diskriminan $74,00-101,10$; disusul berturut-turut dari campuran pulp pelepah nipah $(75 \%)$ dan pulp sabut kelapa (25\%) pada konsentrasi alkali $8-12 \%$, memiliki selang nilai 63,90-94,75; dari campuran pulp pelepah nipah $(50 \%)$ dan pulp sabut kelapa $(50 \%)$ juga pada konsentrasi alkali $8-12 \%$, memiliki selang nilai 51,96-71.01; hingga nilai diskrininan terendah $(29,44-70,42)$ yaitu MDF dari pulp sabut kelapa $100 \%$ pada konsentrasi alkali $12 \%$. Perbedaan hasil telaahan antara sistim skor dan sistim persamaan diskriminan terjadi karena pada sistim skor semua sifat MDF yang diamati (Y1, Y2, ...., Y10) dibobot sama, sedangkan pada sistim persamaan determinan, nilai pembobotan tidak sama.

Persamaan diskriminan tersebut mengindikasikan bahwa peranan masing-masing sifat MDF terhadap nilai diskriminan (mutu produk) sebagaimana diindikasikan dari nilai bobotnya (bi; nilai absolut), yaitu mulai dari yang terbesar hingga terkecil berturut-turut emisi formaldehida $(100,54)$, ketahanan panas $(-100,52)$, berat jenis/ kerapatan $(57,09)$, kadar air $(-55,12)$, daya hantar panas $(-46,98)$, MOR $(36,39)$, IB $(32,99)$, pengembangan tebal $(-31,68$, MOE $(24,56)$, dan akhirnya penyerapan air yang terendah $(-1,66)$.

Indikasi lebih berprospeknya serat pelepah nipah tersebut dari pada sabut kelapa menunjukkan bahwa aspek atau karakteristik positif serat pelepah nipah yang dikehendaki untuk MDF (antara lain serat lebih panjang, daya tenun serat lebih tinggi, kadar selulosa dan hemiselulosa lebih besar, pulp nipah lebih mudah digiling, dan waktu giling pulp lebih singkat) mendominir aspek negatifnya (antara lain dinding serat lebih tebal, diameter lumen lebih kecil, kadar silika tinggi, porsi jaringan parenkhim lebih tinggi, rendemen pulp lebih rendah, pemakaian alkali pada pengolahan pulp lebih tinggi, dan daya hantar panas MDF lebih rendah). Namun demikian bila mengacu pada persyaratan JIS (JIS, 2003), sifat fisis dan mekanis MDF (berikut emisi formaldehida) yang dibuat dari pulp pelepah nipah dan campurannya dengan pulp sabut kelapa pada proporsi tertentu sebagian besar tidak memenuhi persyaratan tersebut (Tabel 8).

\section{F. Pencermatan dengan XRD}

Pencermatan dengan alat XRD terhadap bahan serat menunjukkan bahwa kristalinitas pelepah nipah lebih tinggi dibandingkan pada sabut kelapa (Tabel 2). Hal ini mendukung indikasi lebih tingginya kadar lignin dan lebih rendahnya kadar selulosa pada sabut kelapa, dan ikut mempertegas lebih kakunya serat sabut kelapa. Lebih tingginya kristalinitas tersebut berperan positif pada kekuatan individu serat pelepah nipah, sehingga lebih memperkuat penjelasan antara lain pulp pelepah nipah lebih mudah digiling (tidak mudah rusak) dan sifat kekuatan MDF dari pelepah nipah (MOR, MOE, dan IB) yang lebih tinggi dibandingkan dari sabut kelapa.

Fenomena ini sejalan dengan hasil pencermatan oleh peneliti-peneliti terkait (Smook dan Kocurek, 1993; DeBolt, 2008; Wikipedia, 2012a) yang mennyatakan bahwa semakin tinggi kristalinitas bahan serat berligno-selulosa, maka rantai-rantai polimer semakin terorientasi sejajar 
satu dengan yang lainnya sehingga porsi amorfnya berkurang. Hal ini berakibat bahan serat lebih fleksibel dan kekuatan individu serat meningkat baik secara lateral atupun memanjang, yang selanjutnya berpengaruh positif terhadap sifat produk turunannya seperti pulp, kertas, rayon, dan MDF.

Sudut mikrofibril (MFA) serat pelepah nipah (Tabel 2) ternyata lebih rendah dibandingkan selang MFA pada beberapa jenis kayu daun lebar (19,48-31,68) (Roliadi et al., 2010). Diduga perbedaan tersebut terjadi karena pelepah nipah termasuk golongan tumbuhan monokotil sedangkan kayu daun lebar termasuk dikotil, walaupun keduanya termasuk golongan Angiospermae.

\section{KESIMPULAN DAN SARAN}

Hasil pencermatan secara rinci melibatkan seluruh aspek (sifat bahan baku/pengolahan pulp/fisik-mekanis dan emisi formaldehida MDF) mengindikasikan bahwa pelepah nipah lebih prospektif sebagai bahan baku MDF dibandingkan sabut kelapa. Penggunaan sabut kelapa tetap bisa prospektif, dengan mencampurkan sabut tersebut (sesudah dibentuk jadi pulp) dengan pulp pelepah nipah dengan porsi $(\mathrm{b} / \mathrm{b})$
$25 \%+75 \%$ dan $50 \%+50 \%$ ). Dari pencermatan aspek sifat bahan baku saja, ternyata serat sabut kelapa berindikasi lebih prospektif sebagai bahan baku untuk papan serat berkerapatan sedang (MDF).

Pencermatan terhadap aspek sifat pengolahan pulp saja untuk MDF pada berbagai variasi konsentrasi alkali menunjukkan hal hampir serupa, di sini prospek pulp sabut kelapa sedikit lebih tinggi. Pencermatan terhadap aspek sifat fisis dan mekanis MDF berikut emisi formaldehida mengindikasikan bahwa penggunaan pelepah nipah lebih prospektif dibandingkan sabut kelapa.

Pencermatan dengan alat XRD terhadap bahan serat mengindikasikan bahwa kekuatan individu serat pelepah nipah lebih tinggi dibandingkan serat sabut kelapa. Penggunaan bahan aditif perekat UF cenderung meningkatkan sifat fisis dan mekanis MDF, dan penggunaan aditif arang aktif menurunkan emisi formaldehida, tetapi menurunkan sifat fisis dan mekanis tersebut.

Sebagian besar sifat fisis dan mekanis MDF dari sabut kelapa berikut emisi formaldehida banyak yang tidak memenuhi persyaratan JIS, akan tetapi MDF dari pelepah nipah lebih banyak memenuhi persyaratan dibandingkan MDF sabut kelapa.

Tabel 2. Kristalinitas dan sudut mikrofibril (MFA) bahan serat

Table 2. Crystallinity and microfibril angle (MFA) of fiber stuffs

\begin{tabular}{clcc}
\hline No & \multicolumn{1}{c}{$\begin{array}{c}\text { Macam bahan serat } \\
\text { (Kind of fiber stuffs) }\end{array}$} & $\begin{array}{c}\text { Kristalinitas } \\
\text { (Crystallinity) }\end{array}$ & MFA \\
\hline 1 & Pelepah nipah (Nypha midrib) & 41,43 & 12,24 \\
& a. Ujung (Top/ upper portion) & 48,65 & 14,08 \\
& b. Tengah (Middle) & 55,59 & 20,81 \\
& c. Pangkal (Bottom/ lower portion) & 48,56 & 15,71 \\
& d. Rata-rata (Means) & 43,13 & - \\
2 & Serbuk nipah (Coconut coir) & 22,69 & - \\
\hline & & & \\
\hline
\end{tabular}

Keterangan (Remarks): MFA = Sudut mikrofibril terhadap sumbu serat (Microfibrill angle to the fiber axes); - tidak bisa dilakukan (karena berbentuk serbuk) / Unable to be examined due to being in tiny-particle shapes 


\section{DAFTAR PUSTAKA}

Arsyad, A.J. 2010. Kajian proses produksi pulp berbahan baku sabut kelapa (Cocos nucifera) dengan metode soda pulping. Skripsi. Fakultas Teknologi Pertanian. Institut Pertanian Bogor. Bogor (Tidak Diterbitkan).

Blomquist, R.F., A.W. Christianses, and R.H. Gylespie. 1981. Adhesive bonding of wood and other structural materials. Forest Products Laboratory, Forest Service, USDA - the University of WisconsinExtension. The Pennsylvania State Univ. Univ. Park, PA.

Browning, B.L. 1967. The Chemistry of Wood. Interscience Publishers, A Division of John Wiley and Sons. New York - Toronto London.

Casey, J.P. 1980. Pulp and Paper Chemistry and Techology. Third edition, Vol. I. A WileyInterscience Publication. New York Brisbane-Toronto.

Chemical. 2004. Thermal conductivity of pure carbon. Website: www.chemical.com. Diakses pada tanggal 10 Oktober 2011.

De Bos, T.U. dan B.M. Adnan. 1958. Ilmu Tumbuh-tumbuhan untuk Murid-murid SMP. Cetakan ke Lima. J.B. Wolters. Jakarta.

DeBolt, S. 2008. Relative crystallinity of plant biomass: Studies on assembly, adaptation and acclimation. Website: www.plosone.org/ article/info:doi/ 10.1371/jurnal.pone.0002897. Diakses: 25 Februari 2012.

Dephut. 2008. Statistik Kehutanan Indonesia. Departemen Kehutanan (Dephut). Jakarta.

Diydata. 2010a. Medium density fiberboard (MDF). Website: www.diydata.com. Diakses pada tanggal 7 Oktober 2011.

Ebnesajjad, S. 2008. Adhesives Technology Handbook. William Andrew. Norwich, NY, USA.
Haygreen, J.G. and J.L. Bowyer, 1999. Forest Products and Wood Science. Iowa State University. Ames, Iowa.

IPIRTI. 2012c. Adhesives: Lignin formaldehyde (LF) resin as a partial substitute for PF resin. Indian Plywood Industries Research and Training Institute (IPIRTI. Website: http://www.ipirti.gov. in/adhesives5.html. Diakses: tanggal 15 Juni 2012.

Iskandar, M.I. dan A. Supriadi. 2010. Pengaruh kadar perekat terhadap sifat papan partikel sabut kelapa. Buletin Hasil Hutan, 16 (2): 87-92. Pusat Litbang Hasil Hutan. Bogor.

ISO/DIS. 2009b. ISO/DIS (International Standardization Organization / Draft Internationlal Standard) 27769-2, Woodbased panels - Wet process fiberboard, part 1: Specification; and ISO/DIS 16895-2, Wood based panels - Dry process fiberboartd: Requirements. SC/TC 89/SC1. Geneva, Switzerland.

JIS. 2003. Japanese Industrial Standard (JIS): Fiberboard. JIS A 5905. Tokyo, Japan.

Kompas. 2006. Kayu alam distop total: Laju degradasi hutan 2,87 juta ha per tahun. Harian Kompas, tanggal 28 April 2006, hlmn 22. Kompas. Jakarta.

Labosky, P., R.D. Yobp, J.J. Janowiak, and P.R. Blankenhorn. 1998. Effect of steam pressure refining and resin levels on the properties of UF-bonded red maple MDF. Forest Products Journal, 43 (11/12): 82-87.

Morrison, D.F. Multivariate Statistical Methods. 2003. Second ed. McGraw-Hill Book Co. New York - London-Tokyo - Torono.

P3KKPHH. 2010. Studi pengembangan bahan bakar nabati di Provinsi Riau. Pusat Litbang Keteknikan Kehutanan dan Pengolahan Hasil Hutan (P3KKPHH). Bogor.

PT. Masari Dwisepakat Fiber. 2009. Masari Board. Environmentally Friendly Product. PT. Masari Dwisepakat Fiber. Jakarta Karawang. 
Santoso, A. 2000. Pengaruh komposisi perekat lignin-fenol-formaldehida terhadap keteguhan rekat kayu lapis tusam. Buletin Penelitian Hasil Hutan, vol. 17 (4): 189-198. Pusat Litbang Hasil Hutan, Badan Litbang Kehutanan, Departemen Kehutanan. Bogor.

2011. Tanin dan lignin dari Acacia mangium Wild. Sebagai bahan perekat kayu majemuk masa depan. Orasi Pengukuhan Profesor Riset Bidang Pengolahan Hasil Hutan, 25 Oktober 2011. Badan Litbang Kehutanan, Kementrian Kehutanan. Jakarta.

Saptadi, D. 2009. Kualitas papan isolasi dari campuran kayu mangium dan arang. Jurnal Penelitian Hasil Hutan, vol. 27 (4): 291-302. Pusat Litbang Keteknikan Kehutanan dan Pengolahan Hasil Hutan. Bogor

SAS Institute Inc. 1997. SAS (Statistical Analysis System) Guide for Personal Computers, Version 6 Edition. SAS Institute Inc. Cary, NC. 27512-8000.

Sazanov, Y.N. and A.V. Gribanov. 2010. Thermochemistry of lignin. Russian Journal of Applied Chemistry, 83 (2): 175194. Website: www.springerlink.com/ content. Diakses: tanggal 22 April 2012

Silitonga, T., R.M. Siagian, dan A. Nurachman. 1972. Cara pengukuran dimensi serat kayu dan bahan serat berligno-selulosa lain di Lembaga Penelitian Hasil Hutan (LPHH). Publikasi khusus 12 (8): 1-17. LPHH. Bogor

Sjostrom, E. 1993. Wood Chemistry: Fundamental and Applications. Academic
Press, Inc. New York - Toronto - Sydney Tokyo.

Smook, G.A. and M.J. Kocurek. 1993. Handbook for Pulp and Paper Technologists. Joint Textbook Committee of the Paper Industry. Atlanta, Georgia.

Snedecor, G.W. and W.G. Cochran. 1980. Statistical Methods. Fifth edition. Iowa State Univ. Press. Ames, Iowa.

Suchsland, O. and G.E. Woodson. 1986. Fiberboard manufacturing practices in the United States. USDA Forest Service. Agricultural Handbook No. 640.

TAPPI Press. 2006. Technical Association of the Pulp and Paper Industry (TAPPI)'s Test Methods. TAPPI Press. Atlanta, Georgia.

Tsoumi, G. 1993. Science and Technology of Wood: Structure, Properties, and Utilization. Van Nostrand Reinhold. New York.

Wikipedia. 2009. Nipah. Website: http://id.wikipedia.org/wiki/Nipah. Diakses 14Januari 2011.

Wikipedia. 2012. Thermal conductivity and heat resistance of material. Website: en.wikipedia.org/Thermal_conductivity. Diakses pada tanggal 26 Pebruari 2012.

Wikipedia. 2012a. Cellulose. Website: en.wikipedia.org/Cellulose. Diakses pada tanggal 26 Pebruari 2012.

Wikipedia. 2012b. Urea formaldehyde adhesive. Website: en.wikipedia.org/wiki/ureaformaldehyda. Diakses pada tanggal 27 April 2012. 